https://doi.org/10.52058/2708-7530-2021-12(18)-78-85

Кузьмичук Олександир Валерійович аспірант кафедри управління та бізнес-адміністрування, Інститут післядипломної освіти та довузівської підготовки, ДВНЗ «Прикарпатський національний університет імені Василя Стефаника», вул. Шевченка, 57, м. Івано-Франківськ, 76018, тел.: (034)2788105, e-mail: oleksandr.kuzmychuk@pnu.edu.ua, https://orcid.org/0000-0001-7004-6416

Вичівський Павло Павлович кандидат історичних наук, доцент кафедри управління соціокультурною діяльністю, шоу-бізнесу та івентменеджменту, Прикарпатський національний університет імені Василя Стефаника, вул. Галицька 201Б, м. Івано-Франківськ, е-mail: pavlo.vuchivskui@pnu.edu.ua, https://orcid.org/ 0000-0003-4415-7635

Шикеринець Василь Васильович кандидат наук 3 державного управління, доцент, завідувач кафедри управління соціокультурною діяльністю, шоу-бізнесу та івентменеджменту, Прикарпатський національний університет імені Василя Стефаника, вул. Галицька 201Б, м. Івано-Франківськ, e-mail: vasyl.shykerynets@pnu.edu.ua, https://orcid.org/0000-0002-6845-1639

\title{
РЕАЛІЗАЦІЯ ДЕРЖАВНОЇ ПОЛІТИКИ В СФЕРІ ГОСТИННОСТІ
}

Анотація. У статті здійснений аналіз особливостей реалізації державної політики у сфері гостинності. В цьому контексті підкреслено, що зміст реалізації державної політики складає сукупність завдань, цілей, програм, пріоритетів розвитку, які розробляють і реалізують органи державної. Реалізація державної політики у сфері гостинності на сучасному етапі, це процес цілеспрямованої діяльності органів управління на державному та місцевому рівнях в більшості випадків на основі наперед прийнятих програм, які мають на меті подолання комплексних проблем розвитку сфери гостинності, а також розвитку суспільства в цілому.

Відзначено, що нормативно-правова база функціонування сфери гостинності в України складається 3 Конституції України та інших законодавчих актів України, а також міжнародних договорів та угод які ратифіковані в Україні. Регулювання вітчизняною галуззю гостинності здійснюється Верховною Радою України, Кабінетом Міністрів України, місцевими державними адміністраціями, органами місцевого самоврядування, а також центральними та регіональними органами виконавчої влади в галузі туризму та іншими установами в межах їх повноважень.

Окрема увага приділяється створенню - Єдиного туристичного реєстру 
(ЄTP). Головним завданням СТР є розробка і координація ефективної комунікації усіх суб'єктів сфери гостинності, а також здійснення комплексної статистичної діяльності. За допомогою ЄТР створюється можливість для будь-кого перевірити актуальну інформацію про діяльності туроператора, турагента або готелю.

Реалізації державної політики у сфері гостинності здійснюється за допомогою певного набору методів та функцій. Головні функції державного управління сферою гостинності, здійснюється на двох рівнях: національному і регіональному. Перспективи розвитку індустрії гостинності в Україні в основному залежать від реалізації ефективної державної політики у сфері туризму, яка має поєднуватися 3 продуманою стратегією просування на зовнішні ринки вітчизняного туристичного продукту. Не менш важливим $\epsilon$ якісно новий підхід до формування дієвих механізмів реалізації державної політики у сфері гостинності, які б сприяли розвитку малого та середнього бізнесу, збереженню та розвитку конкурентного середовища на ринку послуг сфери гостинності, підвищенню значення сфери гостинності у вітчизняній економіці, а також зміцненню позитивного іміджу сфери гостинності України.

Ключові слова: сфера гостинності України, державна туристична політика, державне регулювання туристичної галузі, туристична політика, організаційний процес державного регулювання туризму.

Kuzmychuk Oleksandyr Valeriiovych Postgraduate student of the Department of Management and Business Administration, Institute of Postgraduate Education and Pre-University Training,Vasyl Stefanyk Precarpathian National University, Shevchenka St., 57, Ivano-Frankivsk, 76018, tel.:(034) 2788105, e-mail: oleksandr.kuzmychuk@pnu.edu.ua, https:/orcid.org/0000-0001-7004-6416

Vychivskyi Pavlo Pavlovych Phd in historical sciences, Departament of Management Socio-Cultural Activity Management, Show Business and Event Management, associate dean Faculty of Tourism, Vasyl Stefanyk Precarpathian National University, 57, Shevchenko St., Ivano-Frankivsk, 76018, tel.: (095)126-1040, e-mail: pavlo.vuchivskui@pnu.edu.ua, https:// orcid.org/0000-0003-4415-7635

Shykerynets Vasyl Vasylovych Phd in public administration, Associate Professor, Head of the Department of Sociocultural Activities Management, Show Business and Event Management, associate dean Faculty of Tourism, Vasyl Stefanyk Precarpathian National University, 76018, Ivano-Frankivsk, 57, Shevchenko Str., tel.: (095)42-39-468, e-mail: vasyl.shykerynets@pnu.edu.ua, https://orcid.org/00000002-6845-1639

\section{IMPLEMENTATION OF STATE POLICY IN THE FIELD OF HOSPITALITY}

Abstract. The article analyzes the peculiarities of the implementation of state policy in the field of hospitality. In this context, it is emphasized that the content of 
the implementation of public policy is a set of tasks, goals, programs, development priorities, which are developed and implemented by public authorities. Implementation of state policy in the field of hospitality at the present stage is a process of purposeful activity of government bodies at the state and local levels in most cases on the basis of pre-established programs aimed at overcoming complex problems of hospitality and society as a whole.

It is noted that the legal framework for the functioning of the hospitality industry in Ukraine consists of the Constitution of Ukraine and other legislative acts of Ukraine, as well as international treaties and agreements ratified in Ukraine. The domestic hospitality industry is regulated by the Verkhovna Rada of Ukraine, the Cabinet of Ministers of Ukraine, local state administrations, local governments, as well as central and regional executive bodies in the field of tourism and other institutions within their powers.

Special attention is paid to the creation of the Unified Tourist Register (UTR). The main task of UTR is to develop and coordinate effective communication of all subjects of the hospitality sector, as well as the implementation of comprehensive statistical activities. With the help of UTR it is possible for anyone to check the latest information about the activities of a tour operator, travel agent or hotel.

The implementation of state policy in the field of hospitality is carried out using a set of methods and functions. The main functions of public administration in the field of hospitality are carried out at two levels: national and regional. Prospects for the development of the hospitality industry in Ukraine mainly depend on the implementation of an effective state policy in the field of tourism, which should be combined with a well-thought-out strategy to promote foreign tourism product on foreign markets. Equally important is a qualitatively new approach to the formation of effective mechanisms for implementing state policy in the field of hospitality, which would promote small and medium business, maintain and develop a competitive environment in the hospitality market, increase the importance of hospitality in the domestic economy and strengthen positive image of the hospitality industry of Ukraine.

Keywords: hospitality sphere of Ukraine, state tourism policy, state regulation of tourism industry, tourism policy, organizational process of state regulation of tourism.

Постановка проблеми. Сучасна суспільно-політична ситуація в Україні, яка склалася внаслідок Революції Гідності, спрямована в першу чергу на розвиток демократичного устрою, а також децентралізації влади. На даний час, вітчизняна сфера гостинності знаходиться на етапі подолання досить тривалої, глибокої кризи спровокованої агресією Російської Федерації, та як наслідок анексією Криму та війни на сході України, а також пандемією COVID-19. На середину 2021 року сфера гостинності України займає досить низькі позиції серед інших сегментів вітчизняної економіки. Не сприяє розвитку сфери 
України і ряд інших факторів, зокрема: низька якість вітчизняного продукту сфери гостинності, незадовільний стан нормативно-правової бази; економічна нестабільність; досить часті політичні кризи, нерозвиненість вітчизняної інфраструктури сфери гостинності, а також відсутність чіткої стратегії сфери гостинності та ін.

В той же час, в більшості розвинених країнах світу (на державному рівні) створені національні організації сфери гостинності, першочерговим завданням яких $\epsilon$ концептуальне управління розвитком сфери гостинності. Рівень повноважень та компетенцій таких структур у різних країнах варіюється в залежності від стану розвитку сфери гостинності. Водночас, в нашій державі ще не склалася збалансована система державного управління сферою гостинності, яка в цілому не відповідає сучасним потребам, та є неефективною. Вдосконалення функціонування та розвитку вітчизняної сфери гостинності може стати можливим, в першу чергу завдяки ефективній реалізації державної політики даною сферою.

Аналіз останніх досліджень і публікацій. Проблема реалізації державної політики в сфері гостинності, знайшла своє висвітлення у працях багатьох вітчизняних науковців. Зокрема, сучасний стан нормативно-правового регулювання сфери гостинності досліджували: П. Мельник, В. Биркович, С. Домбровська, I. Валентюк, О. Білотіл, С. Дітковська, Г. Старостенко, Є. Козловський, Л. Томаневич, Н. Свірідова, та інші. Світовий досвід організації та управління сферою гостинності досліджувався у працях Е. Слободенюка, Г .Шаповала, Ю. Алєксєєвої, В. Квартальнова, І. Школи та ін.

Натомість, проблеми пов'язані із правовим регулюванням сфери гостинності знайшли своє відображення у працях В. Вакуленка, 3. Варналія, О. Лебединської, , В. Бакуменка, В. Погорілка, А. Дуровича, О. Серьогіна та інших учених.

Разом 3 тим, комплексні питання пов'язані 3 державною політикою розвитку сфери гостинності досліджували О. Бейдик, М. Бойко О. Любіцева,
М. Мальська,
В. Кифяк,
А. Александрова,
В. Квартальнов,
Т. Ткаченко, С. Шкарлет та інші науковці.

Мета статті - комплексне дослідження сучасних особливостей реалізації державної політики у сфері гостинності.

Виклад основного матеріалу. Сучасний зміст реалізації державної політики у сфері гостинності складає сукупність завдань, цілей, програм, пріоритетів розвитку, які розробляють і реалізують органи державної влади. Комплексний процес реалізації державної політики 3 розвитку сфери гостинності включає наступні етапи:

- ініціатива політики;

- розробка політики;

- виконання політики;

- оцінка політики; 
Реалізація державної політики у сфері гостинності на сучасному етапі, це процес цілеспрямованої діяльності органів управління на державному та місцевому рівнях в більшості випадків на основі наперед прийнятих програм, які мають на меті подолання комплексних проблем розвитку сфери гостинності, а також розвитку суспільства в цілому.

Реалізація державної політики у сфері гостинності, на думку А. Іванова та С. Саламатіної повинна включати систему державного управління, організаційно-управлінську модель, фінансово-економічне забезпечення та нормативно-правову основу. [1.c. 33-39]

Нормативно-правова база функціонування сфери гостинності України складається з Конституції України, Закону України «Про туризм», та інших законодавчих актів України, а також міжнародних договорів та угод які ратифіковані в Україні.

Регулювання вітчизняною сферою гостинності здійснюється Верховною Радою України, Кабінетом Міністрів України, місцевими державними адміністраціями, об’єднаними територіальними громадами, а також центральними та регіональними органами виконавчої влади в сфері гостинності та іншими установами в межах їх повноважень.

Головним документом, який регламентує діяльність в сфері гостинності $€$ Закон України «Про туризм», який був прийнятий Верховною Радою у 1995 р.. У 2003 р. Верховною Радою був прийнятий Закон «Про внесення змін до Закону України «Про туризм», яким визначено основні правові, організаційні, соціально-економічні та виховні принципи реалізації державної політики України в сфері гостинності [2, с.526-527].

В той же час, необхідно відзначити, що 29 квітня 2021 року Верховна Рада України ухвалила законопроект № 4162 про внесення змін до Закону України «Про туризм». Даним документом підкреслено, що внутрішній та в’їзний туризм $\epsilon$ пріоритетними напрямами для розвитку вітчизняної економіки. Не менш важливим $\epsilon$ те, що документом передбачається створення ЄТР - Сдиного туристичного реєстру. Головним завданням ЄТР $\epsilon$ розробка і координація ефективної комунікації усіх суб'єктів сфери гостинності, а також здійснення комплексної статистичної діяльності. Загалом, СТР це - зручний, прозорий електронний механізм онлайн-реєстрації. За допомогою ЄТР створюється можливість для будь-кого перевірити актуальну інформацію про діяльності туроператора, турагента або готелю.

Основною метою прийняття даного Закон $\epsilon$ виконання основних рекомендацій Всесвітньої туристичної організації UNWTO а також імплементація у вітчизняне законодавство головних положень Регламентів та Директив Європейського Союзу які стосуються сфери гостинності. Як відзначають представники Державного агентства розвитку туризму України, прийняття даного закону покращить безпеку та захист вітчизняного туриста. Зокрема, Законом передбачене впровадження обов'язкового страхування на 
випадок неповернення (компенсація усіх витрат, пов’язаних з проживанням, харчуванням та поверненням туриста в Україну), окрема увага приділяється створенню типового договору між туроператором i туристом, а також вказуються вимог до безпеки усіх закладів розміщення. I чи не найважливішим елементом даного закону, $є$ можливість на місцевому рівні фінансування різноманітних програм розвитку сфери гостинності, через створення спеціальних фондів сфери гостинності [3].

Реалізації державної політики у сфері гостинності здійснюється за допомогою певного набору методів та функцій. Зокрема, А. Іванов та С. Саламатіна виділяють наступні функції та методи державного регулювання зазначеною сферою (функції - методи):

1. Загальна організація та правова регламентація діяльності в сфері гостинності - розробка угод та процедури їх підписання, правове визначення єдиних понять у сфері гостинності, затвердження порядку отримання туристами віз а також перетину кордону та провезення товару;

2. Планування розвитку сфери гостинності - створення концепцій та стратегій розвитку сфери гостинності та інфраструктури даної сфери, регулювання розміщення об'єктів сфери гостинності;

3. Регулювання окремих видів діяльності - регулювання систем ліцензування, сертифікації та стандартизації сфери гостинності

4. Забезпечення безпеки сфери гостинності - стандартизація та сертифікація продуктів сфери гостинності, страхування, державно-приватне партнерство з органами МВС, регулювання діяльності рятувальних служб тощо;

5. Кадрове забезпечення сфери гостинності - створення спеціалізованих державних програм підготовки та перепідготовки спеціалістів сфери гостинності, систематичне підвищення кваліфікації працівників підприємств сфери гостинності;

6. Забезпечення наукових досліджень ринку сфери гостинності маркетингові дослідження сфери гостинності, створення та діяльність національних центрів розвитку сфери гостинності, інформаційний супровід діяльності підприємств сфери гостинності;

7. Підтримка зовнішньоекономічної діяльності - створення представництв підприємств сфери гостинності за кордоном, підписання міжнародних договорів, міжнародна реклама вітчизняних продуктів сфери гостинності;

8. Забезпечення охорони історико-культурних пам'яток та довкілля створення законів та особливих умов економічного стимулювання охорони та реставрації історико-культурних пам'яток, а також відновлення природних ресурсів, фінансування закладів соціокультурної сфери;

9. Створення сприятливого іміджу країни - реклама, маркетинг, інформаційно-аналітична робота, оподаткування та інвестування туристичної сфери гостинності; 
10. Контроль та нагляд за розвитком сфери гостинності - аудит ринку сфери гостинності, систематичний контроль розвитку сфери гостинності, моніторинг міжнародної конкурентоспроможності національного продукту сфери гостинності [1, с33-39].

Аналізуючи особливості реалізації державної політики у сфері гостинності, необхідно висвітлити також класифікацію інструментів державної політики за сферами їх застосування (сфера застосування - інструменти):

1. Економічна сфера - податкове регулювання діяльності в сфері гостинності; цільове фінансування спеціальних програм розвитку сфери гостинності з бюджетів всіх рівнів; розширення інвестицій у людський капітал; створення сприятливого інвестиційного клімату у даній сфері.

2. Інноваційна сфера гостинності - створення умов для інноваційної діяльності у сфері гостинності, податкове стимулювання інноваційної діяльності, розширення можливостей інвестування в різні види господарської діяльності в даній сфері.

3. Науково-освітня сфера - розширення фундаментальних наукових досліджень сфери гостинності; створення інформаційно-аналітичної бази сфери гостинності; розвиток професійних кадрів для підприємств сфери гостинності.

4. Правова сфера - удосконалення нормативно-правової бази сфери гостинності; поліпшення умов ліцензування, сертифікації та стандартизації сфери гостинності; розробка особливих правил в’іззду, виїзду та перебування на території України іноземних туристів 3 врахуванням інтересів даної сфери; митне регулювання; запобігання злочинності та боротьба з корупцією.

5. Соціальна сфера - розвиток соціальних видів гостинності залучення громадських та профспілкових організацій до розвитку сфери гостинності, податкове заохочення підприємств сфери гостинності до надання спеціальних послуг у сфері соціальної гостинності.

6. Сфера організації гостинності - формування позитивного іміджу України на світовому ринку гостинності; промоція вітчизняного продукту сфери гостинності на внутрішньому і світовому ринках; постійна участі в міжнародних виставках, форумах, програмах; багатоцільове використання національної інфраструктури сфери гостинності; координація діяльності щодо залучення державних та приватних інвестицій в сферу гостинності [1, с35-39].

Висновки. Проаналізувавши реалізацію державної політики у сфері гостинності можна підсумувати: по-перше, сучасна вітчизняна система державного управління сферою гостинності має застарілі та досить часто недостатньо дієві заходи.

По-друге, в сьогоднішній день, необхідним є якісно новий підхід до формування дієвих механізмів реалізації державної політики у сфері гостинності, які б сприяли подолання негативних тенденцій у вітчизняній індустрії гостинності, сприяли розвитку малого та середнього бізнесу, збереженню та розвитку конкурентного середовища на ринку послуг сфери 
гостинності, розвитку в їзного та внутрішнього туризму, підвищенню значення сфери гостинності у вітчизняній економіці, зміцненню позитивного іміджу сфери гостинності України, а також створенню та промоції національного продукту сфери гостинності на світових ринках.

По-третє, для реалізації державної політики у сфері гостинності необхідно прийняти і поетапно реалізовувати загальнодержавну стратегію розвитку сфери гостинності, яка була б збалансованою відносно ресурсних можливостей та туристичних потоків в країни. У такій стратегії мають бути визначені головні цілі розвитку індустрії гостинності в довгостроковій та короткостроковій перспективах, методи, механізми та критерії їх досягнення, джерела фінансування та терміни виконання.

\section{Лimepamypa:}

1. Іванов А.М., Саламатіна С.Є. Теоретичні основи державної політики розвитку туризму на основі маркетингового підходу в управлінні. Економіка харчової промисловості. Том 8, Випуск 1/2016. С. 33-39.

2. Язіна В.А. Державне регулювання галузі туризму: сутність і шляхи вдосконалення. Глобальні та національні проблеми економіки. Миколаївський національний університет імені В.О. Сухомлинського. Випуск 9. 2016. С. 526-529.

3. Верховна Рада в першому читанні ухвалила новий Закон «Про туризм»: що зміниться? URL: https://www.tourism.gov.ua/blog/verhovna-rada-v-pershomu-chitanni-uhvalilanoviy-zakon-pro-turizm-shcho-zminitsya (Дата звернення: 15.11.2021

\section{References:}

1. Ivanov A.M., Salamatina S. Ye. (2016). Teoretychni osnovy derzhavnoi polityky rozvytku turyzmu na osnovi marketyngovoho pidhodu $\mathrm{v}$ upravlinni.Ekonomika kharchovoi promyslovosti [Theoretical bases of the state policy of tourism development on the basis of the marketing approach in management. Economics of the food industry]. Volume 8, Issue 1[in Ukrainan]

2. Yazina V. A. (2016). Derzhavne reguliuvannia galuzi turyzmu: sutnist ta shliahz vdoskonalennia. Globalni ta natsionalni problemz ekonomiky. Mzkolajivskyy natsionalnyy universytet imeni V. Sukhomlznskogo. [State regulation of tourism: the essence and ways to improve. Global and national economic problems. Mykolayiv National University named after V. Sukhomlynskyy] Issue 9 [in Ukrainan]

3. Verkhovna Rada v pershomu chytanni uhvalyla novyy Zakon "Pro turyzm": scho zminytsia? [ The Verkhovna Rada passed the new Law "On Tourism" in the first reading: what will change?] URL: https://www.tourism.gov.ua/blog/verhovna-rada-v-pershomu-chitanni-uhvalilanoviy-zakon-pro-turizm-shcho-zminitsya (Access date: 11.15.2021) 